\title{
Seasonal peaks and annual fluctuations in recruitment of juvenile scleractinian corals
}

\author{
C. C. Wallace \\ Department of Marine Biology, James Cook University, Townsville 4811, Australia
}

\begin{abstract}
Recruitment of juvenile scleractinian corals to natural calcium carbonate settlement plates varied seasonally and annually on 4 vertically separated reef front sites during a 3 yr study period. Early summer was the major recruiting season: of 1,470 recruits observed on 184 plates over 2 yг, $89 \%$ were in spring-summer (Oct to Feb), $8 \%$ in summer-winter (Feb to Jun) and $3 \%$ in winterspring (Jun to Oct). The peak early summer recruitment was significantly greater in 1980-81 (32 juveniles plate ${ }^{-1}$ ) than in 2 subsequent years (1981-82, 9 plate $^{-1} ; 1982-83,15$ plate $\left.^{-1}\right)$. Sites of greatest recruitment were reef shoulder in the first year, upper reef slope $(6 \mathrm{~m})$ in the second year, and reef flat in the third year. Maximum annual variations in recruitment occurred in 2 shallow sites (reef flat and shoulder). A mid slope site $(12 \mathrm{~m})$ had the lowest overall recruitment and did not vary significantly in annual numbers of recruits. Greater recruitment occurred on undersurfaces of plates at shallow sites but on upper surfaces at deeper sites during all periods. Recruits were mainly from 2 families: Acroporidae, which recruited primarily in spring-summer, and Pocilloporidae, which recruited in all seasons. A shading experiment in 1 spring-summer period indicated that juveniles of some families other than Acroporidae and Pocilloporidae required more protected sites for settlement than those of these 2 families. It is suggested that Acroporidae and Pocilloporidae may be early colonizers of exposed reef substratum, while some other corals may represent later colonists. The seasonal patterns of recruitment described here are compatible with seasonal spawning patterns now known to occur in many Great Barrier Reef corals. Thus, the earlier concept that coral larvae were available at all times of the year must be rejected.
\end{abstract}

\section{INTRODUCTION}

Do corals recruit year round, dropping at any time from an homogenous 'larval soup' to settle on patches of bare reef as they become available? Most previous studies of recruitment of juvenile corals have failed to consider any seasonal or annual variations in availability of larvae; the major concerns have been to address more complex questions about how substratum becomes available, and what effect grazers, competitors and predators, even competitors of grazers, have on the new arrivals (e.g. Birkeland, 1977; Sammarco, 1980; Neudecker, 1982; Sammarco and Carleton, 1982). McGuire and Porter (1977) incorporated biannual recruitment of corals into a model of reef dynamics, this being a compromise between seasonal and year-round availability.

The objective of the present study was to examine temporal variability in availability of coral larvae both throughout the year and between years, concurrently at a number of sites.
Recent work on the Great Barrier Reef has demonstrated that most corals have a well defined annual spawning season, usually in the late spring-early summer (Kojis and Quinn, 1981, 1982a, b; Bothwell, 1982; Harriott, 1983; Babcock, 1984; Harrison et al., 1984) Assuming that length of larval life is short, recruitment of juveniles should also peak during this time. Wallace and Bull (1982) reported heavy recruitment in the late spring-early summer of 1980-81, after a period of very little recruitment from July to October 1980, which indicated an annual recruiting peak. Greater recruitment in the late spring-early summer has also been observed at Heron Island, Southern Great Barrier Reef, by Bothwell (1982); at Lizard Island, Northern Great Barrier Reef, by Harriott (pers. comm.); and in the Central Great Barrier Reef (Sammarco and Carleton. 1982; Sammarco, 1983).

Annual variations in settlement of corals from the plankton have not yet been studied. Variations in success of recruitment have, however, sometimes been judged by recording the presence of colonies large 
enough to be visible to the naked eye. Connell (1973) found variation with site and with year in the magnitude of this type of recruitment on Heron Island reef flat. This stage of recruitment was also studied in conjunction with the present study (Wallace, 1983). and found to represent juveniles remaining approximately 8 mo to 1 yr after settlement.

In the present paper, 'recruitment' is defined as settlement followed by deposition of a recognisable skeleton up to 4 mo old, whether or not the juvenile was still alive at the time of retrieval of the plates. Earlier recruitment phases (e.g. settlement followed by the 'mucoid' skeletal precursor as described by Goreau et al; 1981) cannot be detected by the field methods described here. Removal of the juvenile or the skeleton by predators or grazers was avoided by the type of substratum used (see 'Methods'): thus recruitment approached the criterion of 'settlement' defined by Keough and Downes (1982)

In this paper I examine seasonal recruitment during 2 yr and annual recruitment over 3 yr on 4 vertically separated reef front sites. I also examine the size achieved by corals of maximum age 4 mo. Lack of information on the growth rate of young corals seems to have led to the confusion about the age of corals that are visible to the naked eye (e.g. Connell, 1973). This has led in turn to the idea of a long 'preconditioning' period, usually thought to be about $1 \mathrm{yr}$, before corals can settle (see Pearson, 1981 for summary). Apparent preconditioning in the field can result from the time taken for settled corals to become visible to the naked eye, while apparent preconditioning on settlement plates may reflect seasonal recruitment (Wallace, 1983). This confusion may be resolved by examining corals as soon as possible after they settle.

\section{METHODS}

Study sites. The study sites were on the SW reef front

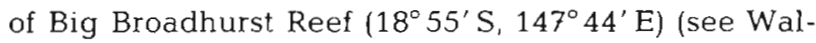
lace and Dale, 1977). Wallace and Bull (1982) described the 4 sites as (1) 'outer reef flat' (at tidal datum), (2) 'reef crest' (just below datum, the reef flat/ slope intersect), (3) 'upper slope' (centered at $6 \mathrm{~m}$ below datum), (4) 'mid slope' (centered at $12 \mathrm{~m}$ below datum). Since the term 'reef crest' has been used variously by different authors and has different local usages, it is replaced in this paper by the term 'reef shoulder', suggested by M. Pichon. After the first year of study, a fifth site, the 'deep slope', centered at $17 \mathrm{~m}$, was added. Results from this site are not used in the analyses of variance but are used elsewhere.

Descriptions of the adult community structure from transect studies are given in Wallace and Bull (1982).
The greatest amount of free substratum unoccupied by hard coral is offered in the mid and deep slope sites, which have less than $50 \%$ coral cover, and the least by the reef shoulder, which has $100 \%$ cover. The cover in the latter site, however, is formed by overlapping tables and arborescent forms of Acropora, and free but shaded substratum is offered underneath the tables The potential settlement to this shaded substratum was studied during one 4 mo period (see below). Temperatures at the sites during the year range from 19 to $30^{\circ} \mathrm{C}$.

The settlement plates were freshly dead pieces of the coral Pocillopora eydouxi (see Wallace and Bull, 1982 for preparation details). These had a complex surface of evenly distributed small cones of equal height, which provided refuge from predators and grazers, and allowed settlement in horizontal, vertical or sloping orientation. Both sides of the plates were equally covered by cones, providing similar upper and lower surfaces for settlement.

This type of plate was chosen to accommodate the following observations from previous studies. (1) Corals recruit well onto natural calcium carbonate substrata (Schuhmacher, 1974, 1977; Sammarco, 1980; Bothwell, 1982; Sammarco and Carleton, 1982). Asbestos and other substances such as 'Novasteen' have not clearly shown effectiveness (Schuhmacher, 1974; Day, 1977), and plastic surfaces may have problems such as accentuated edge effects (Wallace and Bull, 1982). (2) Lack of surface complexity (corners and crevices) probably contributed to low numerical response in many studies (Harrigan, 1972; Harger and Tustin, 1973; Crisp, 1974; Lewis, 1974; Schuhmacher, 1974; Brock 1979; Sammarco, 1980). (3) Juveniles probably have preferred orientations for settlement which might vary with species and location (Birkeland, 1977; Schuhmacher, 1977; Bak and Engel, 1979; Birkeland et al., 1982; Neudecker 1982). (4) Exposure to predators and grazers is sometimes a hazard, but this is avoided when refuges are provided (Schuhmacher, 1974, 1977 : Brock, 1979; Sammarco, 1980; Wellington, 1982).

Two plates were placed on each of 4 wire 'Weldmesh' racks at each site, with their surfaces $10 \mathrm{~cm}$ above and parallel to the reef face. Replicate racks were scattered above an area of approximately $5 \mathrm{~m}^{2}$ at each site. When collected after periods of 4 mo (see below), the plates were fixed in $10 \%$ formalin and dried. For examination, each surface (upper and lower) of each plate was marked with ten squares of $10 \mathrm{~cm}^{2}$ each. The plates were examined twice (by 2 different examiners) under a stereo dissecting microscope. When surfaces were heavily covered by algae, this was removed with forceps during the searching process. Juveniles within the squares were marked and counted, giving an upper and a lower surface count per $100 \mathrm{~cm}^{2}$ and a combined surface count per $200 \mathrm{~cm}^{2}$. 
Study of temporal variations in recruitment. Seasonal: Plates were placed for six 4-mo periods over $24 \mathrm{mo}$ : 'winter-spring' (Jun to Oct), 'spring-summer' (Oct to Feb) and 'summer-winter' (Feb to Jun). The only exception was for the first set of plates, which was placed for only $3 \mathrm{mo}$, because of logistic difficulties. The counts on the plates were analysed by two 2-way analyses of variance: total count by period of placement and site (to detect seasonal and site effects) and proportional upper surface count (arcsine transformed for normalization) by period and site (to detect any patterns of preferred orientation at sites). Whenever a significant effect was shown in an ANOVA, a range test (SNK test, see Zar, 1974, p. 151) was conducted on samples pooled for the independent variable concerned

Annual: The October-February plates from 1980-81 and 1981-82 of the seasonal study were used, together with a third set of plates for October 1982 to February 1983, to make comparisons amongst years. Analyses were the same as for seasonal data.

Study of recruitment to plates placed under overhanging tables. In the second spring-summer period (Oct 1981 to Feb 1982), an auxiliary experiment was set up on the reef shoulder. Four racks were placed under overhanging coral tables (Fig. 1), and 2 plates were placed on each of these. When retrieved, the plates were examined for position and taxonomic identity of recruits.

Identification and measurements of juveniles. Juveniles were identified with the help of scanning electron micrographs prepared from representative

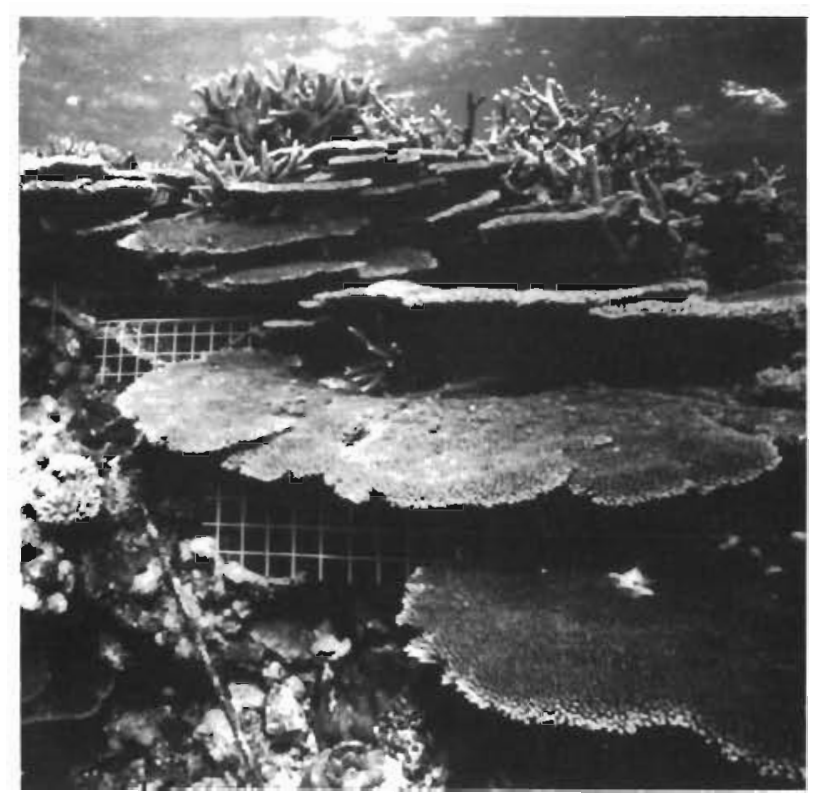

Fig. 1. Racks for settlement plates in auxiliary experiment, placed under overhanging corals at the reef shoulder specimens (taken from plastic petri dish plates, see Wallace and Bull, 1982). By far the majority of specimens were of the genera Montipora and Acropora, which could often be distinguished in photomicrographs, but could not be accurately separated on plates at the 1-polyp stage (most commonly present). This was disappointing, as their distributions in the adult community differ, with Acropora dominating the assemblage at Sites 1 to 3 , and Montipora being an important encrusting genus in Sites 4 and 5. The 2 genera were pooled as Acroporidae. Other juveniles identified to family were Pocilloporidae and Poritidae. All other families were so infrequent that they were pooled as 'others', including ahermatypes (which were also noted separately). Very small or damaged specimens were scored as 'unidentifiable'.

In each of the 3 spring-summer periods, diameters of 40 juveniles per site (20 from each of the upper and lower surfaces) were measured, using a binocular microscope with measuring eyepiece (juveniles were approximately circular at this stage). The juveniles measured were selected at random from circles previously marked on the plates to indicate their presence. Occasionally because of insufficient juveniles in a sample, fewer individuals were sampled.

\section{RESULTS}

\section{Total recruitment}

Greatest overall recruitment was shown by Acroporidae, which accounted for $83.7 \%$ of the recruitment over 2 yr to Sites 1 to 4 (1,231 juveniles), followed by $8.4 \%$ from Pocilloporidae. Poritidae and other groups provided a further $3.5 \%$ of the recruits, and $4.3 \%$ were unidentifiable. For the 3 spring-summer periods combined, Acroporidae made up 83 to $91 \%$ of all recruits, depending on site (Table 1 ). Pocilloporidae recruited to all sites also.

\section{Temporal responses}

\section{Seasonal variations}

Peak recruitment occurred in the 2 spring-summer periods (Oct to Feb), and minimal recruitment in the winter-spring periods (Jun/Jul to Oct) (Fig, 2). The recruitment at different sites showed different seasonal variations (Tables 2 and 3). Recruitment was greater at all sites in spring-summer, but the numbers recruiting to the slope sites changed little from one spring-summer to the next, whereas the shallow sites showed considerable variation (Table 2). 
Table 1 Sites of settlement of taxa in spring-summer over 3 yr (Site 5 for Years 2 and 3 only). $N=$ no. of plates

\begin{tabular}{|c|c|c|c|c|c|c|c|c|c|c|}
\hline \multirow[t]{2}{*}{ Taxa } & \multicolumn{2}{|c|}{ (1) Reef flat } & \multicolumn{2}{|c|}{ (2) Reef shoulder } & \multicolumn{2}{|c|}{ (3) Upper slope } & \multicolumn{2}{|c|}{ (4) Mid slope } & \multicolumn{2}{|c|}{ (5) Deep slope } \\
\hline & No. & $\%$ & No. & $\%$ & No. & $\%$ & No. & $\%$ & No. & $\%$ \\
\hline Acroporidae & 444 & 88.8 & 477 & 85.5 & 392 & 84.8 & 213 & 91.0 & 115 & 83.3 \\
\hline Pocilloporidae & 26 & 5.2 & 43 & 7.7 & 20 & 4.3 & 6 & 2.6 & 9 & 6.5 \\
\hline Poritidae & 4 & 0.8 & 8 & 1.4 & 6 & 1.3 & 1 & 0.4 & 0 & 0 \\
\hline 'Other' & 14 & 2.8 & 12 & 2.2 & 21 & 4.5 & 6 & 2.6 & 11 & 8.0 \\
\hline Unidentifiable & 12 & 2.4 & 18 & 3.2 & 23 & 5.0 & 8 & 3.4 & 3 & 2.2 \\
\hline Total & 500 & & 558 & & 462 & & 234 & & 138 & \\
\hline $\mathrm{N}$ & 24 & & 24 & & 24 & & 23 & & 14 & \\
\hline
\end{tabular}

The reef shoulder received the greatest overall recruitment during the $2 \mathrm{yr}$, almost 3 times that of the mid slope, and more than 1.5 times that at either the reef flat or the upper slope (Table $3 b$ ). The very large recruitment at the reef shoulder during the first spring-

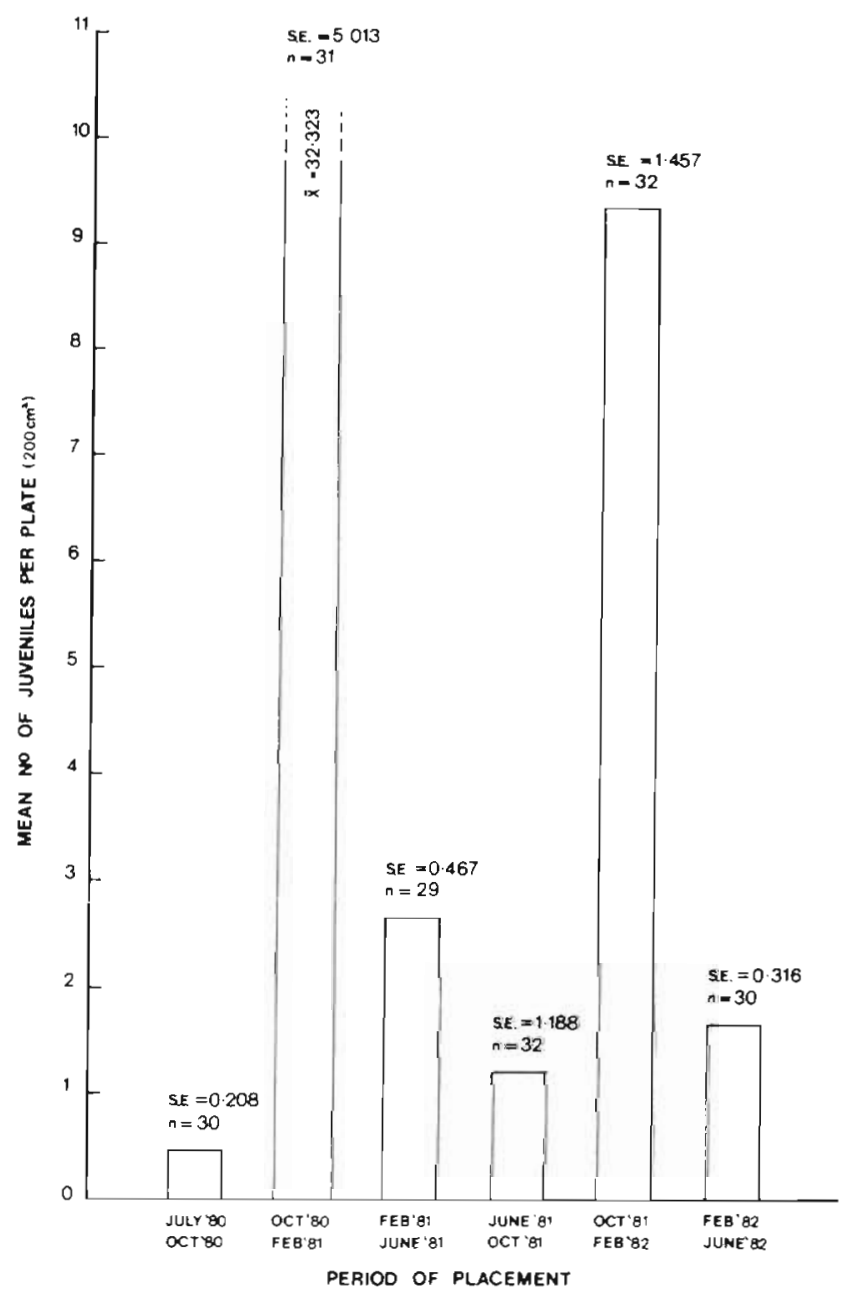

Fig. 2. Mean number of juvenile corals per plate for each 4 mo period over 24 mo (sites pooled) summer period (Fig. 2) had a marked influence on the overall pattern.

Juveniles from families Acroporidae, Poritidae and 'others' recruited predominantly in spring-summer and never in winter-spring (Table 4a). Those from Pocilloporidae recruited throughout all seasons. This was the only group to recruit in winter-spring, although its recruitment also peaked in spring-summer.

\section{Annual variations}

Strong annual variations in numbers of recruits occurred (Table 5a). Overall recruitment in Year 1 was significantly greater than in the following $2 \mathrm{yr}$, being more than 3 times that of Year 2 and twice that of Year 3 (Table 5 b). This $1980-81$ peak was shown by all sites except the mid slope, which did not vary significantly during the $3 \mathrm{yr}$ (Table 2). The site of greatest recruitment shifted from the reef shoulder in Year 1 to the upper slope in Year 2 and the reef flat in Year 3 (Table 2). The upper slope did not vary as much as the 2 shallow sites (reef flat and shoulder), which showed broad variability (Table 2).

During the spring-summer for the $3 \mathrm{yr}$, the proportion of juveniles from Acroporidae and Pocilloporidae remained the same (Table $4 \mathrm{~b}$ ). There was a greater percentage composition of Poritidae during the third year, but the overall numbers for Poritidae were so small that little can be said about this group.

\section{Orientation of juveniles on plates}

At each site, there was a significant difference from a $1: 1$ ratio in recruitment on upper vs lower plate surfaces, when either the seasonal or the annual sets of counts were pooled (Tables $6 a$ and $7 a$ ). This difference was caused by heavier settlement on lower surfaces at the two shallow sites (reef flat and shoulder), and the reverse at the two reef slope sites. This strong influence of site on orientation of recruitment (Tables $6 \mathrm{~b}$ 
Table 2. Mean numbers of juvenile corals per $100 \mathrm{~cm}^{2},( \pm S E$ ) for all plates. $N=$ no. of plates

\begin{tabular}{|c|c|c|c|c|c|c|c|c|c|}
\hline & Site & Surface & $\begin{array}{l}\text { Jul } 1980 \\
\text { to Oct } 1980\end{array}$ & $\begin{array}{c}\text { Oct } 1980 \\
\text { to Feb } 1981\end{array}$ & $\begin{array}{l}\text { Feb } 1981 \\
\text { to Jun } 1981\end{array}$ & $\begin{array}{l}\text { Jun } 1981 \\
\text { to Oct } 1981\end{array}$ & $\begin{array}{l}\text { Oct } 1981 \\
\text { to Feb } 1982\end{array}$ & $\begin{array}{l}\text { Feb } 1982 \\
\text { to Jun } 1982\end{array}$ & $\begin{array}{l}\text { Oct } 1982 \\
\text { to Feb } 1983\end{array}$ \\
\hline (1) & $\begin{array}{l}\text { Reef } \\
\text { flat }\end{array}$ & $\begin{array}{l}\text { Upper } \\
\text { Lower }\end{array}$ & $\begin{array}{l}0.0(0.0) \\
1.0(0.5) \\
(\mathrm{N}=6)\end{array}$ & $\begin{array}{r}6.9(2.7) \\
27.0(4.6) \\
(\mathrm{N}=8)\end{array}$ & $\begin{array}{l}0.1(0.1) \\
1.4(0.4) \\
(\mathrm{N}=8)\end{array}$ & $\begin{array}{l}0.4(0.3) \\
1.9(0.9) \\
(\mathrm{N}=8)\end{array}$ & $\begin{array}{l}1.3(0.6) \\
1.9(0.9) \\
(\mathrm{N}=8)\end{array}$ & $\begin{array}{l}0.6(0.5) \\
0.4(0.3) \\
(\mathrm{N}=8)\end{array}$ & $\begin{array}{c}11.9(3.8) \\
13.6(5.0) \\
(N=8)\end{array}$ \\
\hline (2) & $\begin{array}{l}\text { Reef } \\
\text { shoulder }\end{array}$ & $\begin{array}{l}\text { Upper } \\
\text { Lower }\end{array}$ & $\begin{array}{l}0.3(0.3) \\
0.6(0.4) \\
(N=8)\end{array}$ & $\begin{array}{c}16.0(7.3) \\
40.9(9.6) \\
(N=8)\end{array}$ & $\begin{array}{l}1.3(0.9) \\
0.7(0.4) \\
(\mathrm{N}=7)\end{array}$ & $\begin{array}{l}0.3(0.2) \\
1.0(0.4) \\
(\mathrm{N}=8)\end{array}$ & $\begin{array}{l}2.3(1.2) \\
6.8(1.8) \\
(\mathrm{N}=8)\end{array}$ & $\begin{array}{l}0.2(0.2) \\
0.7(0.3) \\
(\mathrm{N}=6)\end{array}$ & $\begin{array}{l}1.5(0.6) \\
4.4(2.0) \\
(N=8)\end{array}$ \\
\hline (3) & $\begin{array}{l}\text { Upper } \\
\text { slope }\end{array}$ & $\begin{array}{l}\text { Upper } \\
\text { Lower }\end{array}$ & $\begin{array}{l}0.1(0.1) \\
0.0(0.0) \\
(\mathrm{N}=8)\end{array}$ & $\begin{array}{c}22.3(9.1) \\
5.3(1.6) \\
(N=8)\end{array}$ & $\begin{array}{l}0.8(0.3) \\
0.7(0.3) \\
(N=6)\end{array}$ & $\begin{array}{l}0.1(0.1) \\
1.0(0.4) \\
(N=8)\end{array}$ & $\begin{array}{l}9.5(3.6) \\
4.8(1.8) \\
(\mathrm{N}=8)\end{array}$ & $\begin{array}{l}1.3(0.6) \\
1.1(0.6) \\
(\mathrm{N}=8)\end{array}$ & $\begin{array}{c}12.3(5.6) \\
3.1(0.9) \\
(\mathrm{N}=8)\end{array}$ \\
\hline (4) & $\begin{array}{l}\text { Mid } \\
\text { slope }\end{array}$ & $\begin{array}{l}\text { Upper } \\
\text { Lower }\end{array}$ & $\begin{array}{l}0.1(0.1) \\
0.0(0.0) \\
(\mathrm{N}=8)\end{array}$ & $\begin{array}{c}7.0(2.2) \\
1.0(0.7) \\
(\mathrm{N}=7)\end{array}$ & $\begin{array}{l}5.1(1.0) \\
0.0(0.0) \\
(N=8)\end{array}$ & $\begin{array}{l}0.1(0.1) \\
0.0(0.0) \\
(N=8)\end{array}$ & $\begin{array}{l}9.8(2.4) \\
1.1(0.6) \\
(\mathrm{N}=8)\end{array}$ & $\begin{array}{l}2.1(0.4) \\
0.0(0.0) \\
(\mathrm{N}=8)\end{array}$ & $\begin{array}{c}11.3(2.1) \\
2.1(0.9) \\
(N=8)\end{array}$ \\
\hline (5) & $\begin{array}{l}\text { Deep } \\
\text { slope }\end{array}$ & $\begin{array}{l}\text { Upper } \\
\text { Lower }\end{array}$ & - & - & - & - & $\begin{array}{l}6.7(2.4) \\
2.3(1.0) \\
(\mathrm{N}=6)\end{array}$ & $\begin{array}{l}2.0(1.8) \\
0.4(0.2) \\
(\mathrm{N}=5)\end{array}$ & $\begin{array}{l}5.5(2.5) \\
5.1(1.4) \\
(\mathrm{N}=8)\end{array}$ \\
\hline
\end{tabular}

and $7 \mathrm{~b}$ ) was maintained at all sites throughout all times of sampling (Fig. 3).

Patterns of settlement of juveniles from Acroporidae and Pocilloporidae to upper or lower surfaces of plates (Table 8) showed no obvious preference of either family for a particular orientation, other than that which

Table 3. Analyses of seasonal data

(a) Two factor ANOVA of whole plate counts by period of placement and site

\begin{tabular}{lrrr}
$\begin{array}{l}\text { Source of } \\
\text { variation }\end{array}$ & $\begin{array}{c}\text { Degrees } \\
\text { of freedom }\end{array}$ & $\begin{array}{c}\text { Mean } \\
\text { square }\end{array}$ & $F$ \\
\hline Period & 5 & 4665 & $46.41 \%$ \\
Site & 3 & 425 & $4.23 \cdots$ \\
Period $\times$ Site & 15 & 568 & $5.65 \%$ \\
Residual & 160 & 101 &
\end{tabular}

(b) SNK analyses (underlined means are not significantly different at $p=0.05$ )

(i) Mean no. juveniles per plate for each period (sites pooled)

Jul'80 Feb'82 Jun'81 Feb'81 Oct'81 Oct'80 to Oct ' 80 to Jun' 82 to Oct' 81 to Jun' 81 to Feb' 82 to Feb' 81 $\begin{array}{llllll}0.50 & 1.63 & 1.89 & 2.62 & 9.31 & 32.32\end{array}$

(ii) Mean no. juveniles per plate for each site (periods pooled)

\begin{tabular}{|c|c|c|c|}
\hline $\begin{array}{l}\text { Mid } \\
\text { slope }\end{array}$ & $\begin{array}{c}\text { Reef } \\
\text { flat }\end{array}$ & $\begin{array}{l}\text { Upper } \\
\text { slope }\end{array}$ & $\begin{array}{c}\text { Reef } \\
\text { shoulder }\end{array}$ \\
\hline 4.32 & 7.07 & 8.09 & 12.51 \\
\hline
\end{tabular}

could be accounted for by site. The 'other' group showed a preference for settlement on the undersurfaces of plates (Table 8 ), which could be attributed to the presence of 17 ahermatypic corals, all on undersurfaces, in a total of 53 specimens for this group.

\section{Response to placing plates under overhanging coral tables}

Only 16 recruits were found on these 8 plates, and none were Acroporidae or Pocilloporidae. All were of the category 'other', coming from families Faviidae, Mussidae and Dendrophyllidae. These 16 'other' recruits to 8 shaded plates at one time period contrasted markedly with only 12 'other' recruits to 24 exposed plates at this site during the 3 yr of the study.

\section{Sizes of juveniles}

The largest recruit observed after 4 mo immersion in spring-summer was $4.00 \mathrm{~mm}$ and the smallest $0.45 \mathrm{~mm}$, with the overall mean $0.98 \mathrm{~mm}$ ( $\mathrm{SE} \pm 0.02$ ) (Table 9). The juveniles of Year 3 were significantly smaller than those of the previous $2 \mathrm{yr}$ (SNK tests; analysis of variance: $F=13.2 ; 2,428 \mathrm{df}_{;} \mathrm{p}<0.01$ ). This may have been caused by later spawning of corals in the area in 1982; corals at inshore Magnetic Island spawned later in 1982 than in 1981 (Harrison et al., 1984). 
Table 4 . Identities of juveniles (Sites 1 to 4 ). $N=$ no. of plates

\begin{tabular}{|c|c|c|c|c|c|c|c|c|}
\hline \multirow[t]{2}{*}{ Taxa } & \multicolumn{2}{|c|}{$\begin{array}{l}\text { Winter - spring } \\
(\mathrm{Jul} \text { ' } 80 \text { to Oct ' } 80 \\
\text { Jun ' } 81 \text { to Oct ' } 81)\end{array}$} & \multicolumn{2}{|c|}{$\begin{array}{l}\text { Spring - summer } \\
\text { (Oct ' } 80 \text { to Feb. ' } 81 \\
\text { Oct ' } 81 \text { to Feb ' } 82 \text { ) }\end{array}$} & \multicolumn{2}{|c|}{$\begin{array}{l}\text { Summer - winter } \\
\text { (Feb ' } 81 \text { to Jun ' } 81 \\
\text { Feb ' } 82 \text { to Jun ' } 82 \text { ) }\end{array}$} & \multicolumn{2}{|c|}{$\begin{array}{l}\text { All seasons } \\
\text { combined }\end{array}$} \\
\hline & No. & & & $\%$ & & $\%$ & No. & $\%$ \\
\hline Acroporidae & 0 & 0 & 1142 & 87.2 & 89 & 74.2 & 1231 & 83.7 \\
\hline Pocilloporidae & 39 & 95.1 & 76 & 5.8 & 9 & 7.5 & 124 & 8.4 \\
\hline Poritidae & 0 & 0 & 6 & 0.5 & 2 & 1.7 & 8 & 0.5 \\
\hline 'Other' & 0 & 0 & 35 & 2.7 & 9 & 7.5 & 44 & 3.0 \\
\hline Unidentifiable & 2 & 4.9 & 50 & 3.8 & 11 & 9.2 & 63 & 4.3 \\
\hline Total & \multicolumn{2}{|l|}{41} & \multicolumn{2}{|l|}{1309} & \multicolumn{2}{|l|}{120} & \multicolumn{2}{|l|}{1470} \\
\hline$N$ & \multicolumn{2}{|l|}{62} & \multicolumn{2}{|l|}{63} & \multicolumn{2}{|l|}{59} & \multicolumn{2}{|l|}{184} \\
\hline \multicolumn{9}{|c|}{ (b) Annual data } \\
\hline \multirow[t]{2}{*}{ Taxa } & \multicolumn{2}{|c|}{$\begin{array}{c}\text { Year } 1 \\
\text { Oct ' } 80 \text { to Feb ' } 81\end{array}$} & \multicolumn{2}{|c|}{$\begin{array}{c}\text { Year } 2 \\
\text { Oct ' } 81 \text { to Feb } 82\end{array}$} & \multicolumn{2}{|c|}{$\begin{array}{c}\text { Year } 3 \\
\text { Oct } 82 \text { to Feb } 83\end{array}$} & \multicolumn{2}{|c|}{$\begin{array}{c}\text { Years } 1 \text { to } 3 \\
\text { combined }\end{array}$} \\
\hline & No. & $\%$ & No. & $\%$ & No. & $\%$ & No. & $\%$ \\
\hline Acroporidae & 893 & 88.8 & 249 & 82.2 & 384 & 86.3 & 1526 & 87.0 \\
\hline Pocilloporidae & 56 & 5.6 & 20 & 6.6 & 19 & 4.3 & 95 & 5.4 \\
\hline Poritidae & 4 & 0.4 & 2 & 0.7 & 13 & 2.9 & 19 & 1.1 \\
\hline 'Other' & 19 & 1.9 & 16 & 5.3 & 18 & 4.0 & 53 & 3.0 \\
\hline Unidentifiable & 34 & 3.4 & 16 & 5.3 & 11 & 2.5 & 61 & 3.5 \\
\hline Total & 1006 & & 303 & & 445 & & 1754 & \\
\hline $\mathrm{N}$ & 31 & & 32 & & 32 & & 95 & \\
\hline
\end{tabular}

\section{DISCUSSION}

The findings of this study add weight to the challenge (e.g. by Birkeland et al., 1982; Doherty, 1982; Underwood and Denley, 1984) to models which give no consideration to availability of larvae or to circumsettlement events as factors potentially affecting population or community dynamics. There are a number of ways in which these models might be modified to include variable recruitment of corals.

Table 5. Analyses of annual data. NS: not significant

(a) Two factor ANOVA of whole plate counts by site

\begin{tabular}{lcrc}
$\begin{array}{l}\text { Source of } \\
\text { variation }\end{array}$ & $\begin{array}{c}\text { Degrees } \\
\text { of freedom }\end{array}$ & $\begin{array}{c}\text { Mean } \\
\text { square }\end{array}$ & F \\
\hline Year & 2 & 4399 & $16.67 \cdots$ \\
Site & 3 & 656 & $2.49 \mathrm{NS}$ \\
Year $\times$ Site & 6 & 1548 & $5.87 \cdots$ \\
Residual & 83 & 263 &
\end{tabular}

(b) SNK analysis (underlined means are not significantly different at $\mathrm{p}=0.05$ )

Mean no. juveniles per plate for each year

$\begin{array}{ccc}\text { Year } 2 & \text { Year 3 } & \text { Year 1 } \\ 9.31 & 15.03 & 32.32\end{array}$

$\cdots=$ significant at $P=0.01$

\section{Seasonality}

Most coral larvae settle out of the plankton during a single limited time period each year. This strong seasonal pattern was obvious at all sites during the pre-

Table 6. Settlement of juvenile corals. NS: not significant

(a) Orientation of settlement of juvenile corals on plates at each site, from seasonal data, all seasons pooled

\begin{tabular}{|c|c|c|}
\hline \multicolumn{2}{|c|}{$\begin{array}{l}\text { Observed } \\
\text { total counts }\end{array}$} & \multirow{2}{*}{$\begin{array}{c}\chi^{2} \text { for } \\
\text { departure } \\
\text { from } 1: 1\end{array}$} \\
\hline $\begin{array}{l}\text { Upper } \\
\text { surface }\end{array}$ & $\begin{array}{l}\text { Lower } \\
\text { surface }\end{array}$ & \\
\hline 74 & 251 & $95.6^{\cdots}$ \\
\hline 160 & 403 & $104.2 \cdot$ \\
\hline 271 & 101 & $76.8^{\cdots}$ \\
\hline 187 & 16 & $143.0^{\circ}$ \\
\hline
\end{tabular}

(b) Two factor ANOVA of arcsine transformed proportion on upper plate surface by season

\begin{tabular}{|c|c|c|c|}
\hline $\begin{array}{l}\text { Source of } \\
\text { variation }\end{array}$ & $\begin{array}{l}\text { Degrees } \\
\text { of freedom }\end{array}$ & $\begin{array}{l}\text { Mean } \\
\text { square }\end{array}$ & F \\
\hline Season & 5 & 0.34 & $1.51 \mathrm{NS}$ \\
\hline Site & 3 & 6.51 & $29.04 \cdots$ \\
\hline Season $\times$ Site & 15 & 0.31 & $1.39 \mathrm{NS}$ \\
\hline Residual & 105 & 0.22 & \\
\hline
\end{tabular}


Table 7. Settlement of juvenile corals. NS: not significant

(a) Orientation of juvenile corals on plates at each site, from annual data, Years 1 to 3 pooled

\begin{tabular}{|c|c|c|c|c|}
\hline & \multicolumn{2}{|c|}{$\begin{array}{l}\text { Observed } \\
\text { total counts }\end{array}$} & \multirow{2}{*}{$\begin{array}{c}\chi^{2} \text { for } \\
\text { departure } \\
\text { from } 1: 1\end{array}$} \\
\hline & & $\begin{array}{l}\text { Upper } \\
\text { Surface }\end{array}$ & $\begin{array}{l}\text { Lower } \\
\text { surface }\end{array}$ & \\
\hline (1) & Reef flat & 160 & 340 & $64.1 \cdots$ \\
\hline (2) & Reef shoulder & 158 & 416 & $115.1^{\cdots}$ \\
\hline (3) & Upper slope & 352 & 105 & $132.7^{\cdots}$ \\
\hline (4) & Mid slope & 217 & 33 & $134.0^{\circ}$ \\
\hline (5) & Deep slope & 84 & 55 & $5.7^{\cdots}$ \\
\hline
\end{tabular}

(b) Two factor ANOVA of arcsine transformed proportion on upper plate surface by year and site

\begin{tabular}{lccc}
$\begin{array}{l}\text { Source of } \\
\text { variation }\end{array}$ & $\begin{array}{c}\text { Degrees } \\
\text { of freedom }\end{array}$ & $\begin{array}{c}\text { Mean } \\
\text { square }\end{array}$ & $F$ \\
\hline Year & 2 & 0.06 & $0.37 \mathrm{NS}$ \\
Site & 3 & 3.30 & $19.88 \cdots$ \\
Year $\times$ Site & 6 & 0.07 & $0.45 \mathrm{NS}$ \\
Residual & 80 & 0.17 & \\
$\cdots=$ significant at $\mathrm{P}=0.01$ & &
\end{tabular}

sent study, a finding which confirms other observations on the Great Barrier Reef (Bothwell, 1982; Harriott and Sammarco, pers. comm.). This phenomenon is correlated with the remarkably coordinated mass spawning event now known to occur in late spring-early summer for a large number of Great Barrier Reef corals (Harrison et al., 1984).

Thus, recruitment as a process of selection from a 'rich and varied pool of larvae available in the water column' (Doherty, 1982) is not equally possible year round, although this situation may well exist during the spring-summer months in some years. The con-

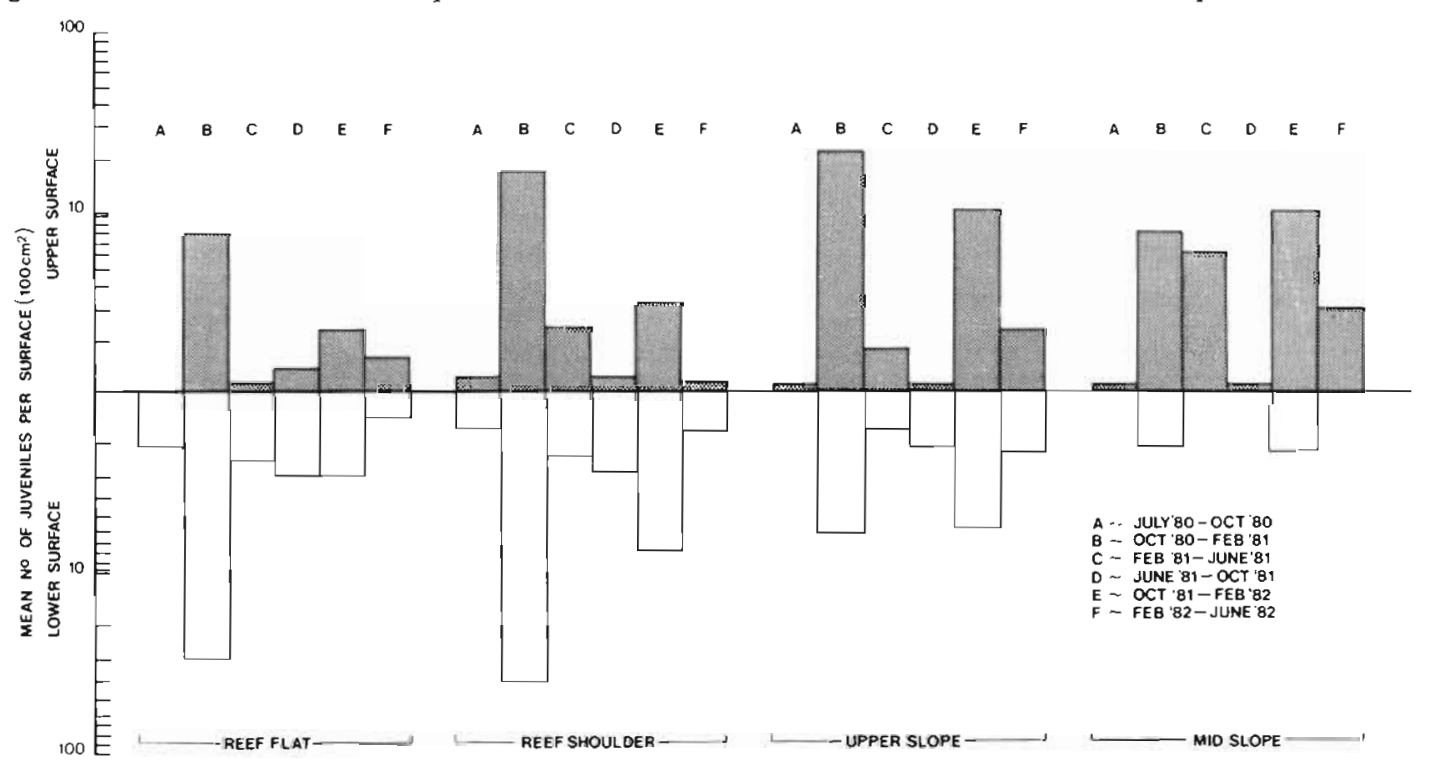

Table 8. Orientation of taxa on plates (as \% on upper surfaces) taken from combined annual data

\begin{tabular}{|lrrrr|}
\hline \multicolumn{1}{|c}{ Taxa } & $\begin{array}{c}(1) \\
\text { Reef } \\
\text { flat }\end{array}$ & $\begin{array}{c}(2) \\
\text { Reef } \\
\text { shoulder }\end{array}$ & $\begin{array}{c}(3) \\
\text { Upper } \\
\text { slope }\end{array}$ & $\begin{array}{c}\text { Mid } \\
\text { slope }\end{array}$ \\
\hline Acroporidae & 34 & 28 & 86 & 82 \\
Pocilloporidae & 8 & 14 & 42 & 57 \\
Poritidae & 0 & 0 & 100 & $0^{\circ}$ \\
'Other & 44 & 33 & 10 & 67 \\
Unidentified & 25 & 6 & 69 & 88 \\
- 1 specimen only & & & & \\
\hline
\end{tabular}

Table 9. Diameters of juveniles measured on plates from all sites from the 3 spring-summer seasons

\begin{tabular}{cccccc|}
\hline Year & $\mathrm{n}$ & $\overline{\mathrm{x}}(\mathrm{mm})$ & $( \pm \mathrm{SE})$ & Range $(\mathrm{mm})$ \\
\hline 1 & 148 & 1.060 & $(0.038)$ & $0.50-4.00$ \\
2 & 132 & 1.052 & $(0.031)$ & $0.45-2.50$ \\
3 & 151 & 0.856 & $(0.025)$ & $0.45-3.00$ \\
Total & 431 & 0.986 & $(0.019)$ & $0.45-4.00$ \\
\hline
\end{tabular}

centration of large numbers and great variety of juveniles during this season may result in intense competition amongst very young corals. Dense recruitment may also provide 'escape' from predators or from other post settlement effects (Underwood and Denley, 1984).

Studies of early stages of recruitment provide a means to test hypotheses regarding larval supplies and consequent population responses, if they are followed by studies in situ on the reef. The seasonal nature of most recruitment should allow year classes to be recog- 
nised and followed. This is being done at the Big Broadhurst study area, where recolonization of cleared patches at Sites 1 to 4 is being followed in close association with the early recruitment study (Wallace, 1983). Results for the $2 \mathrm{yr}$ after the 'Year 1' spring-summer indicate that differential mortality is affecting the relative abundances of taxa in the 2 reef slope sites, but not in the 2 shallow sites (Wallace, unpubl.).

\section{Annual variations}

Significant variability in recruitment from year to year at any site means that certain year groups should have the potential to dominate population and community numbers, and to play a disproportionately large role in the competition for resources. Factors potentially affecting community structure (predators, harsh physical conditions, etc.) must act against this background of variability of recruitment, and their influence on the community as a whole may be moderated or even negated in years of heavy recruitment.

The annual patterns can only be said to be patterns for the particular sites studied, since there are no comparisons made with similar sites elsewhere. This leaves unanswered some tantalizing questions regarding the spatial consistency of the patterns, amongst similar sites on this and other reefs, and these questions have been taken up in a continuation of the present study. On the basis of the relatively great temporal variability of recruitment at the shallow sites versus the deeper sites, it is reasonable to hypothesise that fluctuations in recruitment to similarly placed shallow sites will be greater than those for reef slope sites.

\section{Spatial variability}

The shallow sites had consistently more recruitment than deep sites and great variability in numbers of recruits amongst years. Connell (1978) interpreted greater diversity of corals on 'crests and outer slopes' as being a consequence of greater disturbance on those sites. Disturbance, by removing the shading effects of coral tables at these sites, would change the type of free surface from 'exposed' to 'shaded'. As has been seen in this study, this results in a different taxonomic composition of recruiting larvae. The results indicate, however, that variability of recruitment may also play a part in maintenance of diversity at such sites.

\section{Variety in settlement preference}

The results of the auxiliary experiment, where plates were placed under overhanging coral tables, suggest that the settlement plates in the main experiment may not have provided the correct cues for settlement $f$ ir some coral species. Large scale heterogeneity on the reef surface, in the form of either irregular reef substrate or overhanging live corals, may be necessary before larvae of some species will settle. On the other hand, juveniles from other families may be deterred from settlement in the presence of these features. The main recruits to the exposed plates, from families Acroporidae and Pocilloporidae, may represent early colonizers of newly exposed substratum, while other corals may represent later successional stages, or colonizers of smaller rather than larger patches of free reef substratum. If recruitment to experimentallyplaced settlement plates is to be used as a baseline for examination of post-settlement events, this will have to be taken into account in experimental designs.

The differences with increasing depth between lower and upper surfaces of plates as the preferred sites of settlement were probably due to the changing light regime. It should be pointed out that this was a proportional effect: even in the shallow sites the number of recruits to upper (i.e. less preferred) surfaces was considerable, and was sometimes even greater than at deep sites, where upper surfaces were preferred. Only in the winter months were there cases of no recruits to one or the other surface. Because of the design of the plates, in which refuges were provided for settlement, recruits were not exposed to grazing by fish or echinoids, so differential grazing is irrelevant. The change was not accompanied by a change of taxa, at least at the family level, so it suggests that the same taxa were behaving differently at different depths. Preferences during settlement rather than differential survival are suggested because the skeletons of all settlers, whether they were alive or dead after 4 mo of plate immersion, were scored. Experiments by Sammarco and Carleton (1982) related a similar change in favoured surfaces to diminishing availability of light. Birkeland (1977) found a similar change in patterns of recruitment of corals with depth, which was inversely related to biomass of algae. Bak and Engel (1979) found this pattern and concluded it reflected preferred light intensities.

\section{Rate of early growth in corals}

Even assuming the oldest coral on the plates was only 1 mo old (rather than the possible $4 \mathrm{mo}$ ), the $4 \mathrm{~mm}$ maximum diameter seen is much smaller than the $1 \mathrm{~cm}$ or more sometimes thought to be the diameter reached by a recruit aged 1 mo (e.g. Connell, 1973; Schuhmacher, 1974, 1977). Vaughan (1912) cultured several coral species to yearling status, and found the largest size achieved to be $23 \mathrm{~mm}$ greater diameter and $14.5 \mathrm{~mm}$ lesser diameter. Bak and Engel (1979) 
assumed that corals of up to $40 \mathrm{~mm}$ in situ on the reef were 1 to 3 yr old, and Birkeland (1977) reported a mean diameter of $29 \mathrm{~mm}$ for juveniles on plates set down for periods up to $3.25 \mathrm{yr}$. Thus newly settled corals undergo a phase of some months during which they are too small to be visible to the naked eye, a factor which must be taken into account when assessing recolonization of reef substratum.

There is much to be gained from long-term studies of recruitment of larval corals at one locality, although the problem of spatial variability will also have to be tackled. The present experiments indicate that it may be a relatively easy matter to sample the available pool of larvae of certain taxa, but that a great amount of ingenuity might be needed in order to sample from the whole taxonomic range of coral larvae available at any locality at one time. Absence of a taxon may indicate its rarity in the water column, or it may indicate a lack of provision within the experimental design of the correct cues for settlement. The search for these cues may reveal new aspects of the dynamics of coral communities.

Acknowledgements. The study was founded by grants to M. Pichon and C. C. Wallace from the Marine Science and Technology Grants Scheme and the Great Barrier Reef Marine Park Authority.

I thank E. Lovell and G. Bull for support in the field and G. Bull for discussions and early analyses. B. Miller prepared the graphs, which were figured by G. Kelly. Thanks are due to D. Duncan, J. Barnett and crew of the 'James Kirby'; to 30 divers who worked on the project, especially the following: $D$. Agostino, M. Cockburn, T. Walker, G. Bridle and R. Babcock; and to Y. MacElwain, D. Baldwin, A. Elliott, R. Knight, B. Miller and S. Sorokin who assisted in the laboratory. R. Jones kindly discussed statistical procedures and I thank A. J. Underwood for his paper on analysis of variance. Finally I gratefully acknowledge improvements suggested by whose who read the manuscript: J. H. Connell, J. R. E. Harger, V J. Harriott and A. J. Underwood.

\section{LTTERATURE CITED}

Babcock, R. C. (1984). Reproduction and dispersion of two species of Goniastrea (Scleractinia) from the Great Barrier Reef Province. Coral Reefs 2: 187-195

Bak, R. P. M., Engel, M. S. (1979). Distribution, abundance and survival of juvenile hermatypic corals (Scleractinia) and the importance of life history strategies in the parent coral community. Mar. Biol. 54: 341-352

Birkeland, C. (1977). The importance of biomass accumulation in early stages of benthic communities to the survival of coral recruits. Proc. 3rd Intern. Coral Reef Symp. Miami, p. $16-21$

Birkeland, C, Rowley, D., Randall, R. H. (1982). Coral recruitment patterns at Guam. Proc. 4th Intern. Coral Reef Symp. Manila 1981 (2), p. 339-344

Bothwell, A. M. (1982). Fragmentation, a means of asexual reproduction and dispersal in the coral genus Acropora (Scleractinia: Astrocoeniida: Acroporidae) - a preliminary report. Proc. 4th Intern. Coral Reef Symp. Manila 1981 (2), p. $137-144$

Brock, R. E. (1979). An experimental study on the effects of grazing by parrotfishes and role of refuges in benthic community structure. Mar. Biol. 51 (4): 381-388

Connell, J. H. (1973). Population ecology of reef-building corals. In: O. A. Jones, R. Endean (ed.) Biology and geology of coral reefs. Vol. 2 Biol. 1. Academic Press, New York, p. 205-245

Connell, J. H. (1978). Diversity in tropical rain forests and coral reefs. Science 199: 1302-1310

Crisp, D. J. (1974). Factors influencing the settlement of marine invertebrate larvae. In: Grant, P. T., Mackie, A. M. (ed.) Chemoreception in marine organisms. Academic Press, London

Day, R. W. (1977). Two contrasting effects of predation on species richness in coral reef habitats. Mar. Biol. 44: 1-5

Doherty, P. J. (1982). Coral reef fishes: recruitment-limited assemblages? Proc. 4th Intern. Coral Reef Symp. Manila (2), p. 465-484

Goreau, N. I., Goreau, T. J., Hayes, R. L. (1981). Settling, survivorship and spatial aggregation in planulae and juveniles of the coral Porites porites (Pallas). Bull. mar. Sci. 31 (2): $424-435$

Harger, J. R. E., Tustin, K. (1973). Succession and stability in biological communities. Part 1: Diversity. Int. J. environ. Stud. 5: $117-130$

Harrigan, J. F. (1972). The planula larva of Pocillopora damicornis: lunar periodicity of spawning and substratum selection behavior. Dissertation, University of Hawaii

Harriott, V J. (1983). Reproductive ecology of four scleractinian species at Lizard Island, Great Barrier Reef. Coral Reefs 2: 9-18

Harrison, P. L., Babcock, R. C., Bull, G. D., Oliver, J. K., Wallace, C. C., Willis, B. L. (1984). Mass spawning in tropical reef corals. Science 223: 1186-1189

Keough, M. J., Downes, B. J. (1982). Recruitment of marine invertebrates: the role of active larvae choice and early mortality. Oecologia (Berl.) 54: 348-352

Kojis, B. L., Quinn, N. J. (1981). Aspects of sexual reproduction and larval development in the shallow water hermatypic coral, Goniastrea australiansis (Edwards and Haime, 1857). Bull mar. Sci. 31: 558-573

Kojis, B. L., Quinn, N. J. (1982a). Reproductive strategies in four species of Porites (Scleractinia). Proc. 4th Intern. Coral Reef Symp. Manila 1981 (2), p. 146-151

Kojis, B. L., Quinn, N. J. (1982b). Reproductive ecology of two Faviid corals (Coelenterata: Scleractinia). Mar. Ecol. Prog. Ser. 8: 251-255

Lewis, J. B. (1974). The settlement behavior of planulae larvae of the hermatypic coral Favia fragum (Esper). J, exp. mar. Biol. Ecol. 15: 165-172

McGuire, L. A., Porter, J. W. (1977). A spatial model of growth and competition strategies in coral communities. Ecol. Modelling 3: 249-271

Neudecker, S. (1982). (abstract) Effects of substratum orientation, depth and time on coral recruitment at Guam. Proc. 4th Int. Coral Reef Symp. Manila (2), p. 376

Pearson, R. G. (1981). Recovery and recolonization of coral reefs. Mar. Ecol. Prog. Ser. 4: 105-122

Sammarco, P. W. (1980). Diadema antillarum and its relationship to coral spat mortality: grazing, competition, and biological disturbance. J. exp. mar. Biol. Ecol. 45 (2-3): 245-272

Sammarco, P. W. (1983). Coral recruitment across the Central Great Barrier Reef: a preliminary report. Proc. Great Barrier Reef Conf. Townsville 1983: 245-258 
Sammarco, P. W., Carleton, J. H. (1982). Damselfish territoriality and coral community structure: reduced grazing, coral recruitrnent, and effects on coral spat. Proc. 4th Int. Coral Reef Symp. Manila (2), p. 526-535

Schuhmacher, H. (1974). On the conditions accompanying the first settlement of corals on artificial reefs with special reference to the influence of grazing sea urchins (Eilat, Red Sea). Proc. 2nd Int. Coral Reef Symp. Great Barrier Reef Committee, Brisbane (2), p. 257-267

Schuhmacher, H. (1977). Initial phases in reef development, studied at artificial reef types off Eilat, Red Sea. Helgoländer wiss. Meeresunters. 30: 400-411

Underwood, A. J., Denley, E. J. (1984). Marine community paradigms. In: Simberloff, D., Strong, R. D. Jr., Abele, L. G., Thistle, A. B. (ed.) Ecological communities: conceptual issues and the evidence. Princeton University Press, Princeton
Vaughan, T W. (1912). The Madreporaria and marine bottom deposits of southern Florida. Carnegie Inst. Wash. Year Book No. 10: 147-155

Wallace, C. C. (1983). Visible and invisible coral recruitment. Proc. Great Barrier Reef Conf. Townsville 1983: 259-261

Wallace, C. C., Bull, G. D. (1982). Patterns of juvenile coral recruitment on a reef front during a spring-summer spawning period. Proc. 4 th Int. Coral Reef Symp. Manila (2): $345-350$

Wallace, C. C., Dale, M. B. (1977). An information analysis approach to distribution patterns of the coral genus Acropora on the reef slope. Atoll Res. Bull. 220: 98-110

Wellington, G. M. (1982). Depth zonation of corals in the Gulf of Panama: control and facilitation by resident reef fishes. Ecol. Monogr. 52: 223-241

Zar, J. H. (1974). Biostatistical analysis. Prentice-Hall, New Jersey

This paper was presented by Professor C. Birkeland; it was accepted for printing on October 25, 1984 